\title{
Deep Ocean Changes near the Western Boundary of the South Pacific Ocean
}

\author{
Bernadette M. Sloyan, Susan E. WijfFels, And Bronte Tilbrook \\ Center for Australian Weather and Climate, CSIRO, and CSIRO Wealth from Ocean National Research Flagship, \\ Hobart, Tasmania, Australia \\ Katsuro Katsumata AND AKIHIKo Murata \\ Research Institute for Global Change, JAMSTEC, Yokosuka, Japan \\ ALISON M. MACDONALD \\ Woods Hole Oceanographic Institution, Woods Hole, Massachusetts
}

(Manuscript received 24 September 2012, in final form 7 August 2013)

\begin{abstract}
Repeated occupations of two hydrographic sections in the southwest Pacific basin from the 1990s to 2000s track property changes of Antarctic Bottom Water (AABW). The largest property changes-warming, freshening, increase in total carbon, and decrease in oxygen - are found near the basin's deep western boundary between $50^{\circ}$ and $20^{\circ} \mathrm{S}$. The magnitude of the property changes decreases with increasing distance from the western boundary. At the deep western boundary, analysis of the relative importance of AABW $\left(\gamma^{n}\right.$ $>28.1 \mathrm{~kg} \mathrm{~m}^{-3}$ ) freshening, heating, or isopycnal heave suggests that the deep ocean stratification change is the result of both warming and freshening processes. The consistent deep ocean changes near the western boundary of the southwest Pacific basin dispel the notion that the deep ocean is quiescent. High-latitude climate variability is being directly transmitted into the deep southwest Pacific basin and the global deep ocean through dynamic deep western boundary currents.
\end{abstract}

\section{Introduction}

The repeated occupation of full-depth ocean profiles along selected ocean transects are providing a globally distributed time series of highly accurate ocean properties. These time series data enable the broad-scale quantification of temperature and salinity changes in the deep ocean (Purkey and Johnson 2010; Kouketsu et al. 2011; Purkey and Johnson 2013). In particular, these studies show significant warming and freshening in the high-latitude ocean basins, with the largest changes in the Southern Ocean adjacent to the Antarctic continent and midlatitude basins in the western South Atlantic and Pacific Oceans and eastern Indian Ocean. While the deep ocean temperature change is small, relative to observed warming in the upper $1000 \mathrm{~m}$, the ocean volume below $2000 \mathrm{~m}$ is large and therefore the deep ocean

Corresponding author address: Bernadette M. Sloyan, CSIRO Marine and Atmospheric Research, GPO 1538, Hobart 7001, Tasmania, Australia.

E-mail: bernadette.sloyan@csiro.au temperature change is a significant contribution to the global energy budget and sea level rise, particularly in the Southern Ocean and adjacent ocean basins (Purkey and Johnson 2010, 2013). Kouketsu et al. (2011), from a data assimilation model, and Purkey and Johnson (2012), using the contraction in volume of Antarctic Bottom Water (AABW), both find a slowdown in the southern branch of the meridional overturning circulation associated with a decrease of northward transport and volume of Antarctic Bottom Water. While these large-scale studies provide a global assessment of deep ocean temperature and salinity changes, basin-scale analyses are able to discern the spatial variability and consistency of changes and can explore the potential drivers of the observed changes. This study focuses on the analysis of hydrographic time series profiles near the western boundary of the southwest Pacific basin.

The bottom waters of the southwest Pacific basin are filled by Antarctic Bottom Water and Circumpolar Deep Water (CDW). AABW in the southwest Pacific basin is formed in the Ross Sea and Adélie Land (Carmack 1990; Rintoul 1998) and enters the region via the 
Australian-Antarctic and South Australian Basins (McCartney and Donohue 2007) or directly from the Ross Sea Gyre through deep passages in the PacificAntarctic Ridge (Carmack 1990). The deep circulation of the southwest Pacific basin is dominated by a northwardflowing deep western boundary current. At $32^{\circ} \mathrm{S}$, the deep western boundary current has two current cores: the Kermadec-Tonga Ridge $\left(180^{\circ}\right)$ and at the Louisville Seamount Chain $\left(172^{\circ} \mathrm{W}\right)$. Whitworth et al. (1999) estimate a net northward transport, below $2000 \mathrm{~m}$, of the deep boundary current of $15.8 \pm 9.2 \times 10^{6} \mathrm{~m}^{3} \mathrm{~s}^{-1}$. The bottom water continues to flow adjacent to the western boundary until $10^{\circ} \mathrm{S}$ where the Samoan Passage constricts the boundary current. Northward transport of $10.6 \pm 1.7 \mathrm{~Sv}\left(1 \mathrm{~Sv} \equiv 10^{6} \mathrm{~m}^{3} \mathrm{~s}^{-1}\right)$ has been estimated in the Samoan Passage (Roemmich et al. 1996). Bottom water flowing northward through the Samoan Passage fills the North Pacific deep ocean (Uchida et al. 2007).

Recent studies have shown bottom water warming along the entire circulation pathway of $\mathrm{AABW} / \mathrm{CDW}$ from the Antarctic continental margins to the North Pacific (Kawano et al. 2006; Purkey and Johnson 2010; Kouketsu et al. 2011). Other studies have documented AABW freshening at the formation sites and adjacent ocean basins (Aoki et al. 2005; Jacobs and Giulivi 2007; Rintoul 2007; Purkey and Johnson 2013). In addition to AABW warming and freshening, analyses have revealed a thinning of the AABW layer entering the midlatitude ocean and a decrease in the northward transport of AABW (Kouketsu et al. 2011; Purkey and Johnson 2012). Detectable temperature change and reduced volume of $\mathrm{AABW}$ in basins remote from the water mass formation regions suggest that deep boundary wave dynamics are involved in the rapid transmission of Southern Ocean AABW water mass changes to the North Pacific Ocean (Masuda et al. 2010).

In this study, we find consistent decadal property changes-warming, freshening, increase in total carbon, and decrease in oxygen-near the deep western boundary of the southwest Pacific basin from $50^{\circ}$ to $20^{\circ} \mathrm{S}$, with the largest changes found at the southern extreme of the deep basin. The magnitude of the property changes decreases with increasing distance from the western boundary. The deepening of the deep isopycnal horizon at the western boundary of the southwest Pacific basin results in a decrease of the isopycnal gradient across the basin and a reduction in the northward volume transport of Antarctic Bottom Water into the Pacific Ocean. Analysis of the relative importance of AABW (neutral density, $\gamma^{n}>28.10 \mathrm{~kg} \mathrm{~m}^{-3}$ ) freshening, heating, or isopycnal heave suggests that the deep ocean stratification change is the result of both warming and freshening processes. The consistent deep ocean changes along the

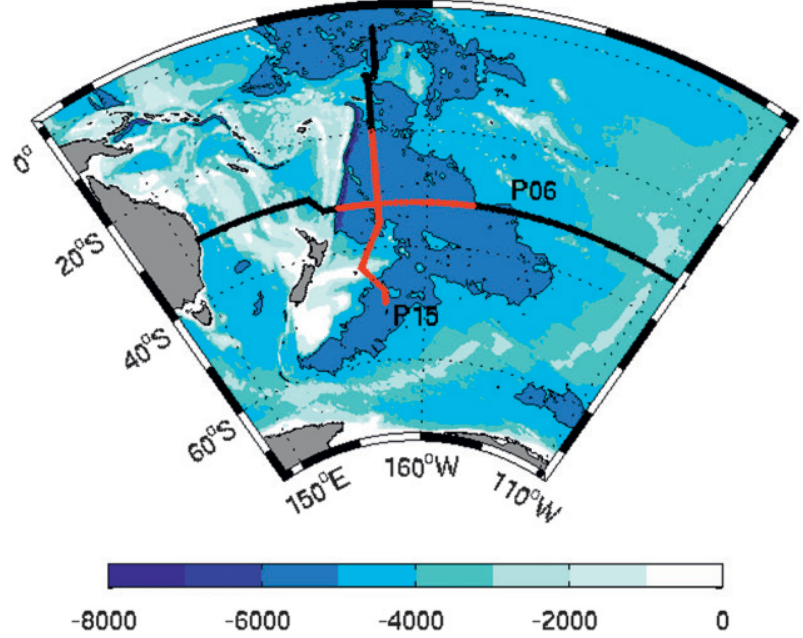

FIG. 1. Location of repeat hydrographic sections (P6 and P15) occupied in the western Pacific Ocean between 1990 and 2009. Hydrographic stations used in this study are shown as red lines. The 5000-m depth contour (black curve) shows the region of the southwest Pacific basin considered in this study. Bathymetry (shading) is at 1000 -m intervals.

western boundary of the southwest Pacific basin confirm a direct link to high-latitude climate variability in the Southern Ocean.

\section{Data}

From six realizations of two sections in the southwest Pacific basin, we estimate the property and volume transport changes below $3500 \mathrm{~m}$ and the spatial distribution of the deep ocean changes near the western boundary (Fig. 1 and Table 1). This study considers hydrographic stations that are located in $>5000$-m water depth or near the western boundary of the basin (Fig. 1). The data were collected as contributions from Japanese, United States, and Australian national research programs to the World Ocean Circulation Experiment (WOCE), Climate Variability and Predictability (CLIVAR), and the Global Ocean Ship-Based Hydrographic Investigations Program (GO-SHIP; http://www.go-ship. org/) and are freely available online (http://cchdo.ucsd. edu/). Only data flagged as good are used in this study. We apply the International Association for the Physical Sciences of the Oceans (IAPSO) Standard Seawater (SSW) batch offsets to the salinity data (Kawano et al. 2006; Purkey and Johnson 2013). In this study, potential temperature is defined using the International Temperature Scale of 1990 (ITS-90), salinity is defined using the Practical Salinity Scale 1978 (PSS-78), and neutral density is defined using Jackett and McDougall (1997). The measurement accuracy of the data are as follows: temperature $0.002^{\circ} \mathrm{C}$, salinity 0.002 PSS-78, oxygen 
TABLE 1. List of hydrographic sections, month/year of occupation, and country. Also given is IAPSO SSW batch number and offset from Purkey and Johnson (2013). Information on the IAPSO SSW batch and offset are provided when available. All data are available online (http://cchdo.ucsd.edu/).

\begin{tabular}{|c|c|c|c|c|}
\hline Section & Month/year & Country & SSW Batch No. & SSW offset $\left(\times 10^{-3}\right)$ \\
\hline P6 & May-July 1992 & United States & P116 & 1.4 \\
\hline \multirow[t]{2}{*}{$\left(32^{\circ} \mathrm{S}\right)$} & August-September 2003 & Japan & P142 & 0.2 \\
\hline & November-February 2009/10 & United States & - & - \\
\hline $\mathrm{P} 15$ & January-March 1996 & United States & P114 & 2.0 \\
\hline \multirow[t]{2}{*}{$\left(170^{\circ} \mathrm{W}\right)$} & May-July 2001 & Australia & $\mathrm{P} 140$ & -0.3 \\
\hline & February-March 2009 & Australia & $\mathrm{P} 148 / \mathrm{P} 150$ & $0.2 / 0.8$ \\
\hline
\end{tabular}

$1-0.5 \mu \mathrm{mol} \mathrm{kg}{ }^{-1}$, and total carbon $1 \mu \mathrm{mol} \mathrm{kg}^{-1}$ (Hood et al. 2010).

Following Purkey and Johnson (2010) we map the vertical properties of potential temperature $\theta\left({ }^{\circ} \mathrm{C}\right)$, salinity $S$ (no units), neutral density $\gamma^{n}\left(\mathrm{~kg} \mathrm{~m}^{-3}\right)$, oxygen $\left(\mu \mathrm{mol} \mathrm{kg}{ }^{-1}\right)$, and total dissolved inorganic carbon ( $\mu \mathrm{mol} \mathrm{kg}{ }^{-1}$; hereafter referred to as total carbon) onto a common vertical and longitudinal or latitudinal grid using Smith and Sandwell (1997) 2-min global bathymetry (Fig. 2). The vertical resolution is $20 \mathrm{dbar}$ from 0 to 6600 dbar. In this study, we only consider the decadal rate of total carbon change and do not attempt to separate the anthropogenic and natural carbon components from total carbon.

Least squares fits are applied to the data to determine time rates of change for ocean properties at each depth and position along the sections. In addition, we map neutral density depth to a common neutral density vertical grid and a least squares fit to depth of density surfaces is applied to determine time rate of change of isopycnal depth. Geostrophic velocity, relative to $\gamma^{n}=$ $28.1 \mathrm{~kg} \mathrm{~m}^{-3}$, for the three realizations of the $32^{\circ} \mathrm{S}$ section
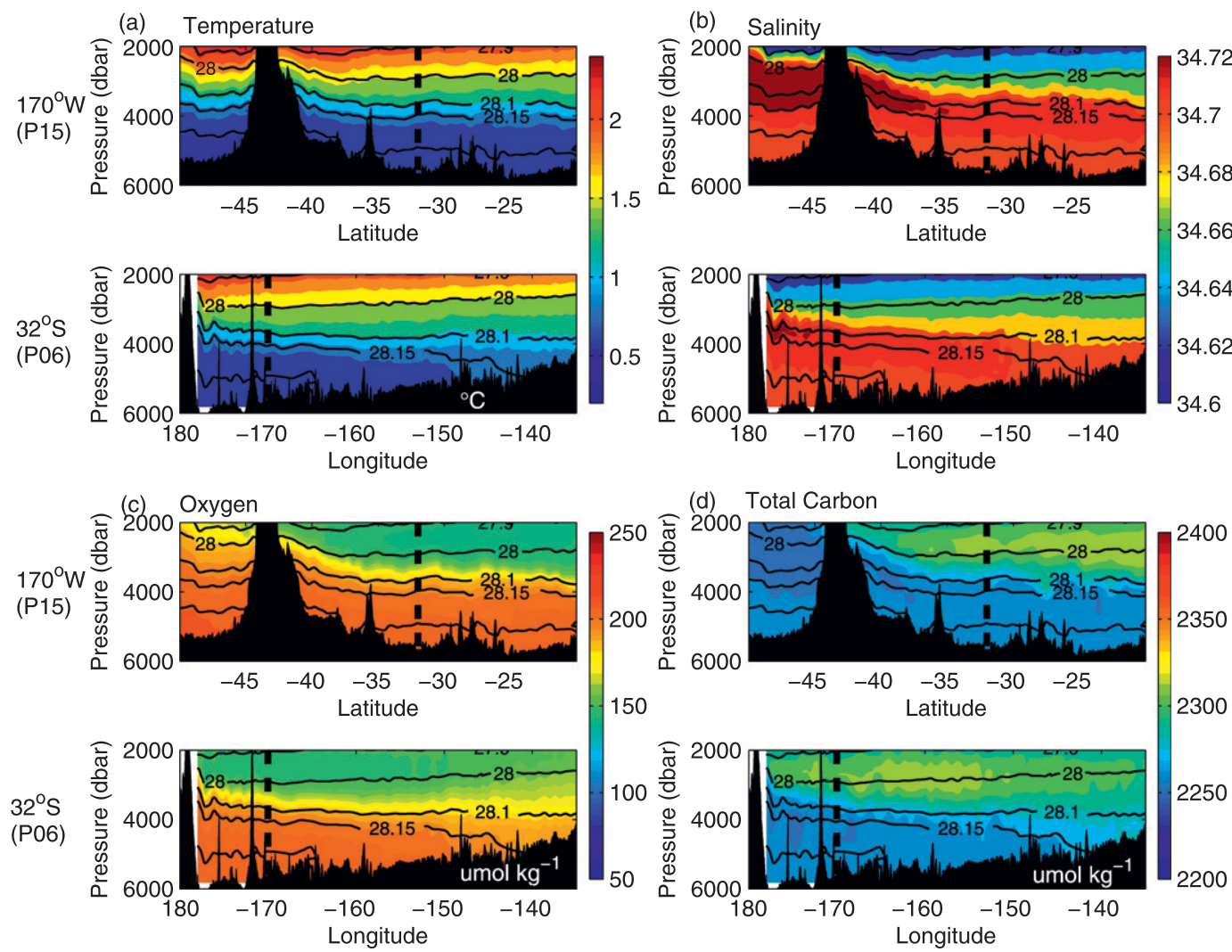

FIG. 2. Property distribution for 2009 of (a) $\theta\left({ }^{\circ} \mathrm{C}\right)$, (b) $S$, (c) oxygen $\left(\mu \mathrm{mol} \mathrm{kg}^{-1}\right)$, and (d) total carbon $\left(\mu \mathrm{mol} \mathrm{kg}^{-1}\right)$ for $170^{\circ} \mathrm{W}\left(\mathrm{P} 15\right.$; between $50^{\circ}$ and $\left.20^{\circ} \mathrm{S}\right)$ and $32^{\circ} \mathrm{S}\left(\mathrm{P} 6\right.$; between $175^{\circ}$ and $\left.135^{\circ} \mathrm{W}\right)$. Distribution of $\gamma^{n}\left(\mathrm{~kg} \mathrm{~m}^{-3}\right)$ is shown and the section cross-over position (boldface dashed line) is marked on each panel. Contours of $\gamma^{n}=27.9,28.0,28.1$, 28.15 , and $28.2 \mathrm{~kg} \mathrm{~m}^{-3}$ are shown. 

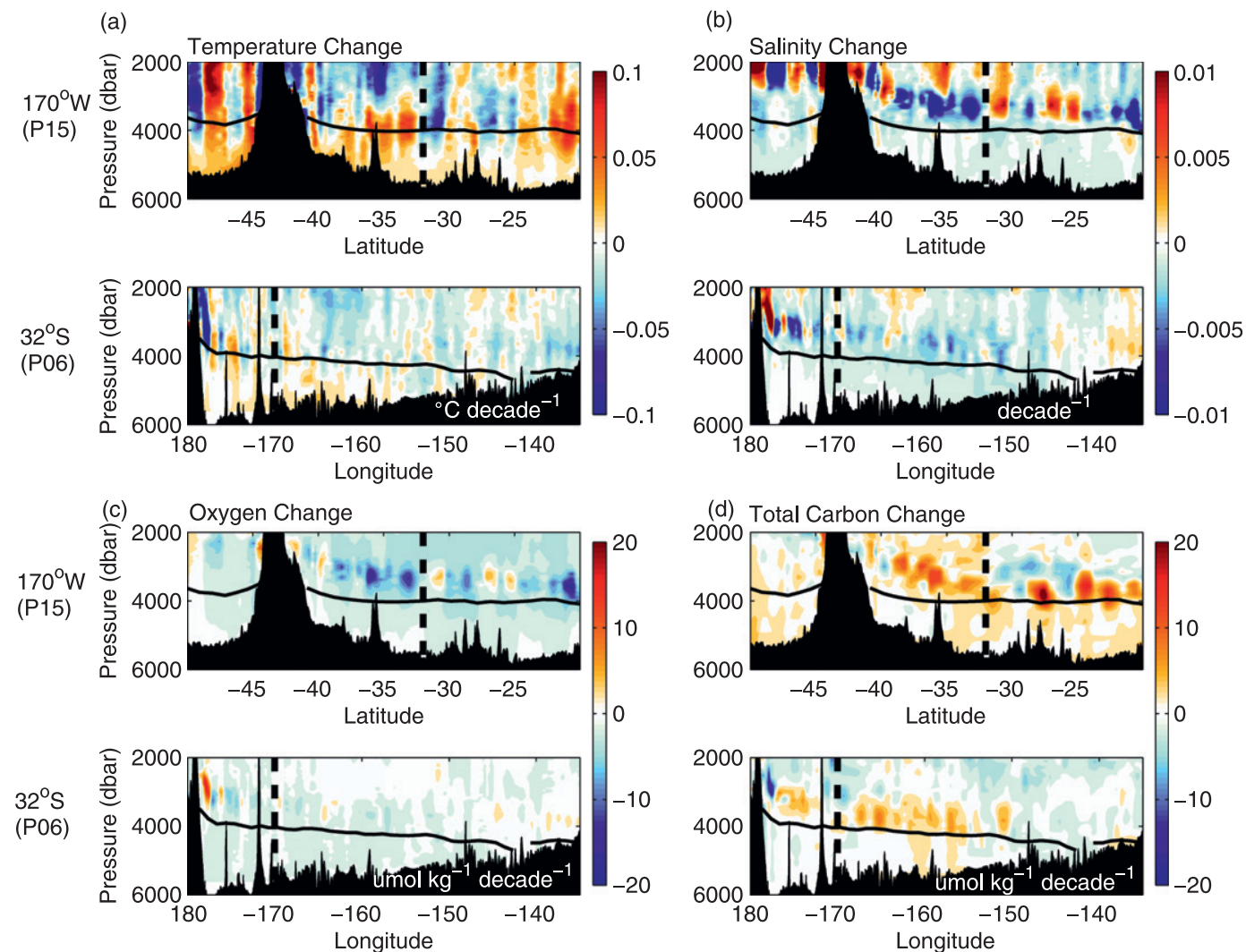

FIG. 3. Decadal rate of change of (a) $\theta\left({ }^{\circ} \mathrm{Cdecade}^{-1}\right)$ (b) $S$ (decade $\left.{ }^{-1}\right)$, (c) oxygen $\left(\mu \mathrm{mol} \mathrm{kg}{ }^{-1} \mathrm{decade}^{-1}\right)$, and (d) total carbon $\left(\mu \mathrm{mol} \mathrm{kg}^{-1} \mathrm{decade}^{-1}\right.$ ) for $170^{\circ} \mathrm{W}(\mathrm{P} 15)$ and $32^{\circ} \mathrm{S}(\mathrm{P} 6)$. The section cross-over position (boldface dashed line) is marked on each panel. The contour of $\gamma^{n}=28.15 \mathrm{~kg} \mathrm{~m}^{-3}$ is shown.

is determined using the Thermodynamic Equation of Seawater-2010 (TEOS-10; Intergovernmental Oceanographic Commission 2010). A Student's $t$ test was applied to determine the $95 \%$ confidence intervals of the basin average rate of property changes, where the degree of freedom of the deep hydrographic data is based on a horizontal decorrelation length scale of $163 \mathrm{~km}$ (Purkey and Johnson 2010).

\section{Decadal property and circulation changes}

\section{a. Deep and bottom water property distribution in the southwest Pacific basin}

The vertical property distributions show the strong property contrasts of the deep and bottom water masses in the southwest Pacific basin (Fig. 2). Along the western boundary $\left[170^{\circ} \mathrm{W}(\mathrm{P} 15)\right], \mathrm{AABW}$ and $\mathrm{CDW}$ are identified by their cold temperatures, high oxygen, and low total carbon concentration that penetrate northward from $50^{\circ}$ to $20^{\circ} \mathrm{S}$ (Figs. 2a,c,d). Remnant North Atlantic Deep Water (NADW) is marked by the slight salinity maximum $(S>34.71)$ above $4000 \mathrm{~m}$ and south of $35^{\circ} \mathrm{S}$
(Fig. 2b). The boundary between CDW and overlying Pacific Deep Water (PDW) is marked by strong vertical gradients in salinity, oxygen, and total carbon (Figs. $2 b, c, d)$.

\section{b. Temperature}

Decadal ocean warming of $>0.03^{\circ} \mathrm{C}$ decade $^{-1}$ below $3500 \mathrm{~m}$ is found adjacent to the western boundary along $170^{\circ} \mathrm{W}$ from $50^{\circ}$ to $20^{\circ} \mathrm{S}$ (Fig. 3a). At $32^{\circ} \mathrm{S}$, deep ocean warming at the western boundary agrees with the magnitude of warming along $170^{\circ} \mathrm{W}$ at a similar latitude, and the magnitude of the warming decreases with increasing distance from the western boundary.

Along the western boundary, below $3500 \mathrm{~m}$, decadal warming south of $43^{\circ} \mathrm{S}$ of $0.023 \pm 0.0007^{\circ} \mathrm{Cdecade}^{-1}$ (not shown) and south of $22^{\circ} \mathrm{S}$ of $0.014 \pm 0.0003^{\circ} \mathrm{Cdecade}^{-1}$ is found (Fig. 4a). The mean basin warming at $32^{\circ} \mathrm{S}$ is $0.006 \pm 0.002^{\circ} \mathrm{Cdecade}^{-1}$. The temperature changes found in this study are similar to previous studies in the same region (Kawano et al. 2006; Johnson et al. 2007) indicating a consistent and continued warming. The warming found in the deep southwest Pacific basin is comparable to warming in the western South Atlantic 
(a) Temperature

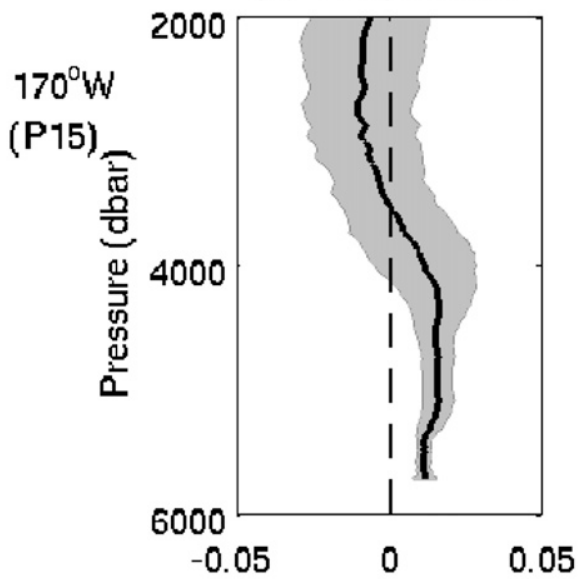

0.05

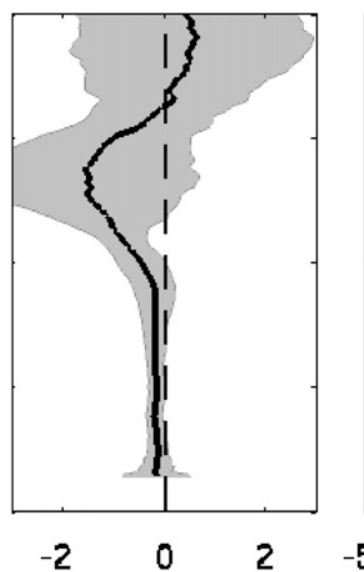

(c) Oxygen

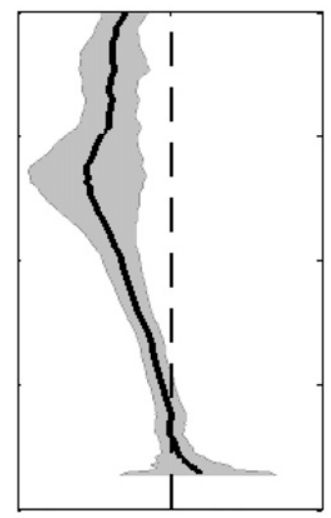

0 (d) Total Carbon

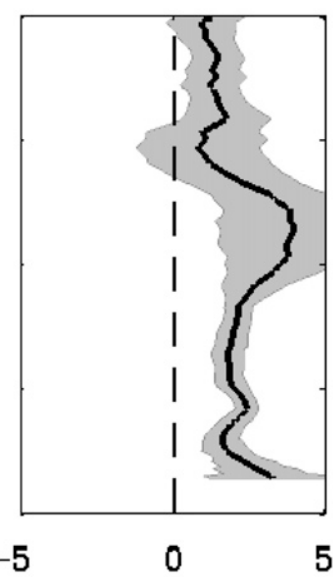

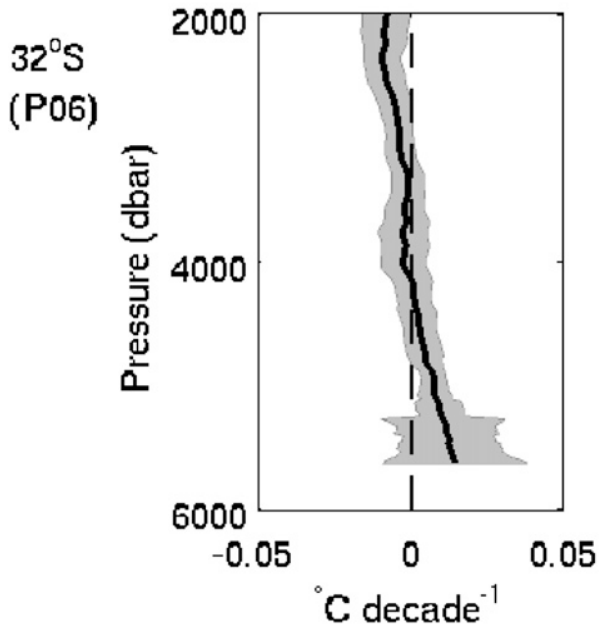
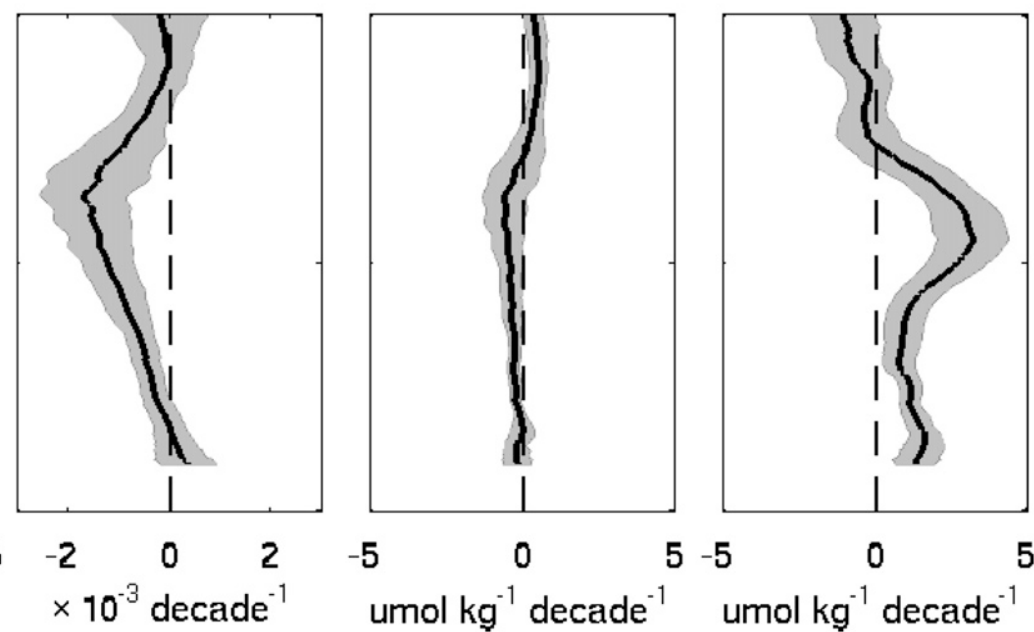

FIG. 4. Deep southwest Pacific basin-average decadal rate of change of (a) $\theta\left({ }^{\circ} \mathrm{Cdecade}^{-1}\right.$ ) (b) $S$ (decade $\left.{ }^{-1}\right)$, (c) oxygen $\left(\mu \mathrm{mol} \mathrm{kg}^{-1} \mathrm{decade}^{-1}\right)$, and (d) total carbon $\left(\mu \mathrm{mol} \mathrm{kg}{ }^{-1} \mathrm{decade}^{-1}\right)$ for $170^{\circ} \mathrm{W}(\mathrm{P} 15)$ and $32^{\circ} \mathrm{S}(\mathrm{P} 6)$. Shading is the $95 \%$ confidence interval.

(Johnson and Doney 2006; Zenk and Morozov 2007) and larger than warming in the Indian Ocean (Johnson et al. 2008).

\section{c. Salinity}

The eddy-like features in the decadal salinity change lying above $\gamma^{n}=28.15 \mathrm{~kg} \mathrm{~m}^{-3}$ identify the boundary between the PDW and CDW (Fig. 3b). Along $170^{\circ} \mathrm{W}$, the boundary between PDW and CDW deepens from $2100 \mathrm{~m}$ at $50^{\circ} \mathrm{S}$ to $4000 \mathrm{~m}$ at $20^{\circ} \mathrm{S}$ (Fig. $3 \mathrm{~b}$ ). Across $32^{\circ} \mathrm{S}$, the horizon of the decadal salinity eddy-like signal deepens from $2100 \mathrm{~m}$ at $180^{\circ}$ to $4000 \mathrm{~m}$ at $150^{\circ} \mathrm{W}$ where it intersects topography.

A consistent decadal salinity decrease is found for AABW along the western boundary $\left[170^{\circ} \mathrm{W}\right.$ (P15), Fig. $3 \mathrm{~b}]$. Across $32^{\circ} \mathrm{S}$, no significant change is seen adjacent to Kermadec-Tonga Ridge $\left(180^{\circ}\right)$; however, freshening is found east of the Louisville Seamount Chain between $170^{\circ}$ and $150^{\circ} \mathrm{W}$ (Fig. 3b). The basin-average rate of salinity change indicates a small, but consistent freshening below $3500 \mathrm{~m}$ near the western boundary (Fig. 3b).

Along the western boundary, a mean freshening below $3500 \mathrm{~m}$ of $-0.0002 \pm 0.0001 \mathrm{decade}^{-1}$ is found (Fig. 4). There is a slightly greater freshening in the western boundary south of $43^{\circ} \mathrm{S}$ of $-0.0003 \pm 0.0003 \mathrm{decade}^{-1}$. The mean across-basin freshening at $32^{\circ} \mathrm{S}$ is $-0.0004 \pm$ 0.0002 decade $^{-1}$. While the observed decadal salinity change is not significantly different from zero or smaller than the measurement accuracy, a consistent freshening signal is found throughout the deep basin. Katsumata and Fukasawa (2011) find a similar deep ocean freshening near the basin's deep western boundary. The magnitude of the basin freshening is similar to freshening 

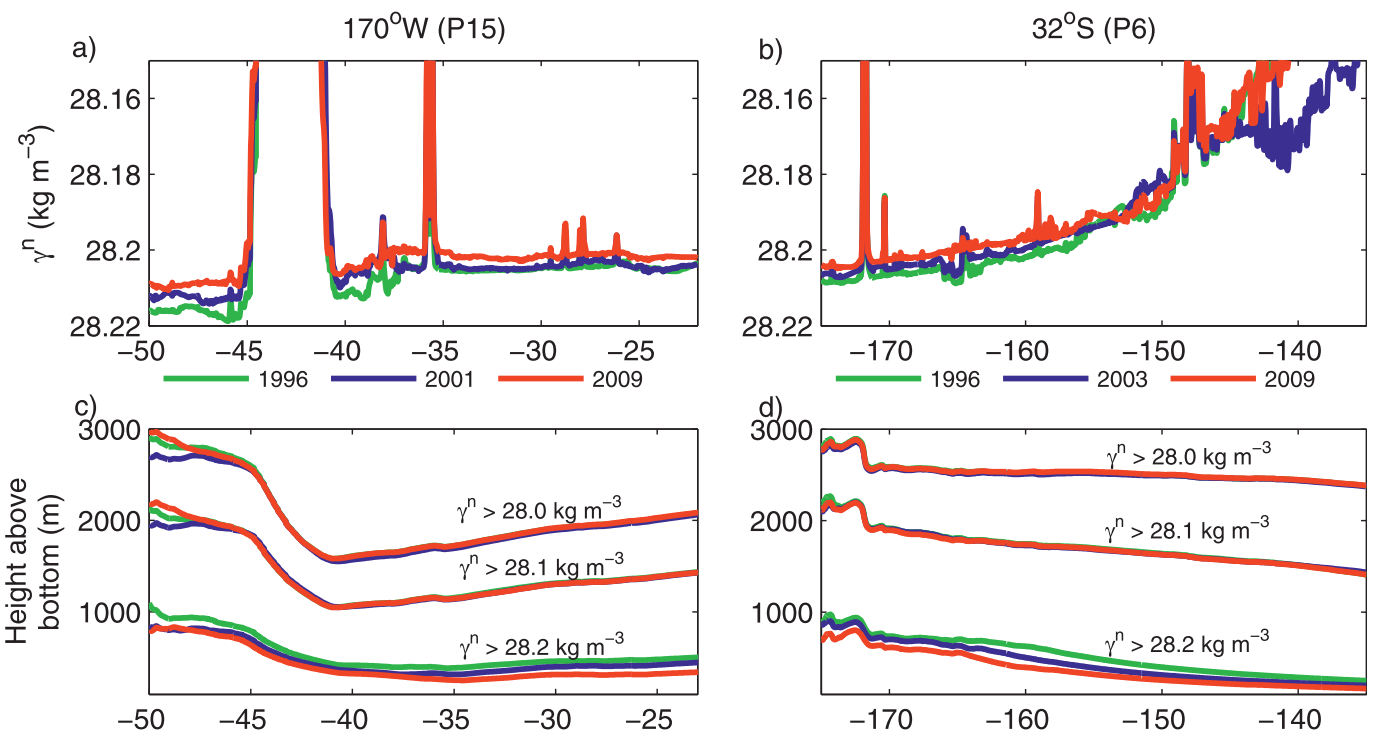

e)
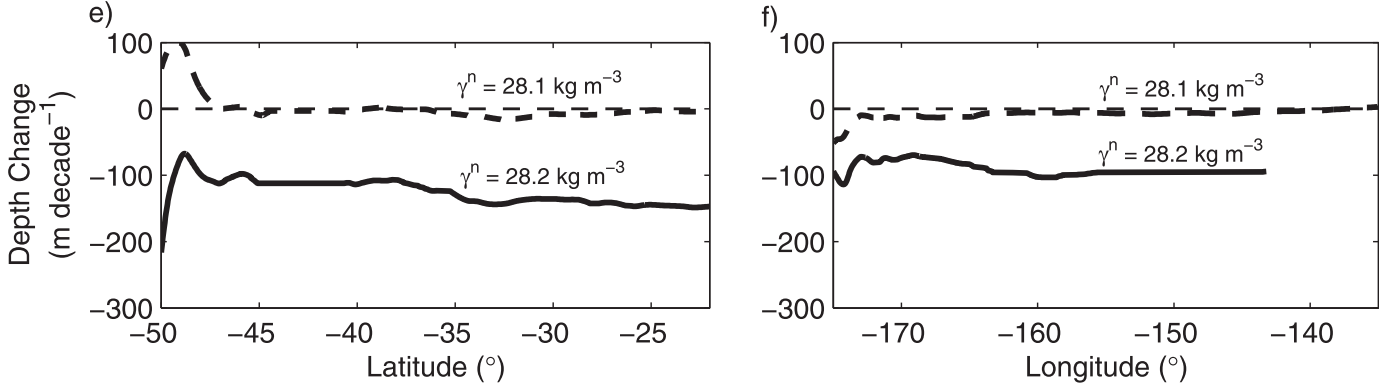

FIG. 5. Bottom $\gamma^{n}\left(\mathrm{~kg} \mathrm{~m}^{-3}\right)$ for (a) $170^{\circ} \mathrm{W}$ (P15) and (b) $32^{\circ} \mathrm{S}$ (P6). Depth of density layer (m) for $\gamma^{n}>28.0,28.1$, and $28.2 \mathrm{~kg} \mathrm{~m}^{-3}$ for (c) $170^{\circ} \mathrm{W}(\mathrm{P} 15)$ and (d) $32^{\circ} \mathrm{S}(\mathrm{P} 6)$. Decadal rate of layer thickness change $\left(\mathrm{m} \mathrm{decade}^{-1}\right)$ for $\gamma^{n}=$ 28.1 and $28.2 \mathrm{~kg} \mathrm{~m}^{-3}$ for (e) $170^{\circ} \mathrm{W}(\mathrm{P} 15)$ and (f) $32^{\circ} \mathrm{S}(\mathrm{P} 6)$.

observed farther to the southwest in the South Australia Basin (Johnson et al. 2008).

\section{d. Oxygen and total carbon}

As for salinity, a strong vertical oxygen and carbon gradient identifies the boundary between CDW and PDW (Figs. 2c,d), resulting in similar eddy-like signals in the decadal oxygen and total carbon change (Figs. 3c,d). Below $3500 \mathrm{~m}$, we find a consistent decadal decrease in oxygen concentration and increase in total carbon concentration (Figs. 3c,d).

The basin-average oxygen change, below $3500 \mathrm{~m}$, along the western boundary south of $43^{\circ} \mathrm{S}$ is $0.15 \pm$ $0.3 \mu \mathrm{mol} \mathrm{kg}^{-1} \mathrm{decade}^{-1}$ and south of $22^{\circ} \mathrm{S}$ is $-0.4 \pm$ $0.3 \mu \mathrm{mol} \mathrm{kg}^{-1}$ decade $^{-1}$ (Fig. 4c). At $32^{\circ} \mathrm{S}$, an oxygen decrease of $-0.2 \pm 0.3 \mu \mathrm{mol} \mathrm{kg}{ }^{-1}$ decade $^{-1}$ is found. Although there is a small and consistent oxygen decrease in the deep basin, it is not significantly different from zero.

A basin-average total carbon increase, below $3500 \mathrm{~m}$, of $2.3 \pm 0.4 \mu \mathrm{mol} \mathrm{kg}^{-1}$ decade $^{-1}$ is found along the western boundary (Fig. 4d). Across the basin, a total carbon increase of $1.3 \pm 0.3 \mu \mathrm{mol} \mathrm{kg}{ }^{-1}$ decade $^{-1}$ is found. A consistent total carbon change is found in the deep basin that is significantly different from zero and larger than the measurement accuracy.

Anderson and Sarmiento (1994) suggest, below $400 \mathrm{~m}$, a biological remineralization P:N: $\mathrm{C}_{\text {org }}$ : $-\mathrm{O}_{2}$ ratio (Redfield ratio) of 1:16 $\pm 1: 117 \pm 14: 170 \pm 10$, and that at $4000 \mathrm{~m}$ the $\mathrm{C}_{\text {org }}$ : $\mathrm{C}_{\text {inorg }}$ ratio is 1 , where $\mathrm{C}_{\text {inorg }}$ is dissolution of particulate inorganic carbon. Thus, in the deep ocean every mole of $\mathrm{CO}_{2}$ generated from remineralization will be accompanied by about 1 mole of $\mathrm{CO}_{2}$ generated by dissolution of particulate inorganic carbon. Therefore, changes in the $\mathrm{CO}_{2}: \mathrm{O}_{2}$ ratio in the deep $\mathrm{Pa}$ cific Ocean will be about 1:- 0.72 owing to oxidation of organic matter and dissolution of particulate inorganic carbon. The observed basin-average total carbon and oxygen changes give a ratio of $1:-0.2$. The departure of the observed ratio from the deep ocean Redfield ratio implies that the decadal total carbon and oxygen changes are not explained solely by biological processes. 


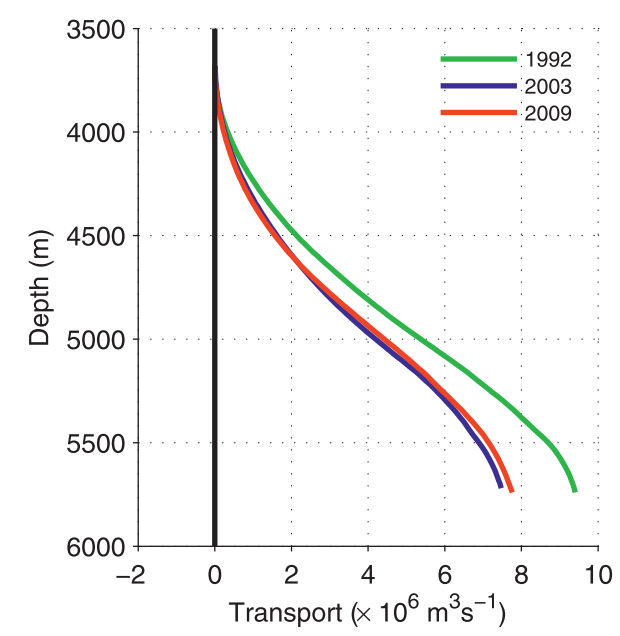

FIG. 6. Vertical downward integral from $3700 \mathrm{~m}$ of the meridional geostrophic volume transport $\left(\times 10^{6} \mathrm{~m}^{3} \mathrm{~s}^{-1}\right)$ across $32^{\circ} \mathrm{S}(\mathrm{P} 6)$ for sections occupied in 1992 (green), 2003 (blue), and 2009 (red). Geostrophic velocity is referenced to $\gamma^{n}=28.1 \mathrm{~kg} \mathrm{~m}^{-3}$.

The total carbon and oxygen changes may be driven by physical processes such as circulation, interior mixing, and air-sea fluxes at AABW formation regions.

\section{e. Neutral density and meridional transport}

The bottom neutral density near the western boundary $\left[170^{\circ} \mathrm{W}(\mathrm{P} 15)\right.$ and $\left.32^{\circ} \mathrm{S}(\mathrm{P} 6)\right]$ for each successive section realization has decreased (Figs. 5a,b). Over the time period of the section occupations, AABW density has decreased resulting in the complete loss of AABW denser than $\gamma^{n}=28.21 \mathrm{~kg} \mathrm{~m}^{-3}$. From the change in depth of isopycnal surfaces, we find a basin increase in depth of $\gamma^{n}=28.2 \mathrm{~kg} \mathrm{~m}^{-3}$ of $100 \mathrm{~m} \mathrm{decade}^{-1}$ and no change in depth of $\gamma^{n}=28.1 \mathrm{~kg} \mathrm{~m}^{-3}$ (Figs. 5c,d).

As for the ocean properties, we calculate the decadal rate of density change on depth levels. Along the western boundary, below $3500 \mathrm{~m}$, the density rate of change is $-2.8 \pm 1.0 \times 10^{-3} \mathrm{~kg} \mathrm{~m}^{-3}$ decade $^{-1}$. The decrease in bottom neutral density and thickness of water of $\gamma^{n}>$ $28.2 \mathrm{~kg} \mathrm{~m}^{-3}$ across the deep southwest Pacific basin (Figs. 5b,d) results in a decrease in the density gradient across the basin between 1996 and 2009. The decrease in the zonal density gradient results in a decrease in the integrated northward geostrophic transport below $\gamma^{n}=$ $28.1 \mathrm{~kg} \mathrm{~m}^{-3}(3700 \mathrm{~m})$ at $32^{\circ} \mathrm{S}$ (P6) of $1.7 \mathrm{~Sv}$ (Fig. 6). This transport decrease mainly reflects changes in the stratification near the western boundary. Kouketsu et al. (2011) and Purkey and Johnson (2012), using an assimilation model and observational data, respectively, find a similar decrease in the northward transport of bottom water in the southwest Pacific basin.

The transport decrease could be the result of circulation changes or decreased production of densest $\mathrm{AABW}$ in the Southern Ocean. To determine the most likely cause of the transport changes, we need to understand further the drivers of the temperature and salinity changes in the deep basin.

\section{Assessment of $\mathrm{AABW}$ property changes}

We can assess the impact of deep ocean freshening, heating, or isopycnal heave as drivers of the deep water mass change by comparing the relative magnitude of the effect these changes have on density. The water mass change attributed to the basin-scale salinity can be expressed as $R_{\rho} /\left.\left(R_{\rho}-1\right) \beta S^{\prime}\right|_{z}$ and the temperature change as $1 /\left.\left(R_{\rho}-1\right) \alpha \theta^{\prime}\right|_{z}$, where the density ratio is $R_{\rho} \equiv \alpha(\partial \theta / \partial z) / \beta(\partial S / \partial z)$, the thermal expansion is $\alpha=$ $-\rho^{-1} \partial \rho / \partial \theta$, and the haline contraction is $\beta=\rho^{-1} \partial \rho / \partial S$ (Bindoff and McDougall 2000). Here, $R_{\rho}, \partial \rho / \partial \theta$, and $\partial \rho / \partial S$ are calculated using the Gibbs Seawater (GSW) Oceanographic Toolbox (McDougall and Barker 2011). A plot of $R_{\rho} /\left.\left(R_{\rho}-1\right) \beta S^{\prime}\right|_{z}$ and $1 /\left.\left(R_{\rho}-1\right) \alpha \theta^{\prime}\right|_{z}$ graphically presents the relative importance of freshwater (freshening or salinification), temperature (warming or cooling), and isopycnal heave as the vector distance from the origin (Bindoff and McDougall 2000).

Adjacent to the western boundary $\left[170^{\circ} \mathrm{W}(\mathrm{P} 15)\right.$ and $32^{\circ} \mathrm{S}$ (P6)] for $\gamma^{n} \geq 28.1 \mathrm{~kg} \mathrm{~m}^{-3}$, the basin water mass changes lie parallel to the freshening and warming axes (Fig. 7a). The deep ocean warming becomes increasingly important for $27.9<\gamma^{n}<28.1 \mathrm{~kg} \mathrm{~m}^{-3}$. This suggests that the decadal change of the AABW $\left(\gamma^{n}>28.1 \mathrm{~kg} \mathrm{~m}^{-3}\right)$ in the southwest Pacific basin is the result of both warming and freshening processes. Interestingly, Kouketsu et al. (2011) show that the halosteric contribution is the largest term in the total steric height change due to deep ocean temperature and salinity changes in the southwest Pacific basin. The warming and freshening of the densest AABW could be attributed to a number of processes; decreased ocean interior mixing between AABW and CDW along the circulation pathway, warming and freshening of $\mathrm{CDW}$, or heat and freshwater changes in the AABW formation regions. We have no observations to consider changes in ocean mixing as a driver of the observed AABW property changes. However, observations of property changes at the formation regions of AABW and in the adjacent basins do allow us to consider whether the AABW changes in the deep southwest Pacific basin are consistent with high-latitude changes.

As stated, we find a warming and a small, but consistent, freshening below $3500 \mathrm{~m}$ near the western boundary of the southwest Pacific basin. AABW entering the Pacific originates from potentially two formation sites in the Pacific and Indian sectors of the Southern Ocean: Ross Sea and Adélie Land. Significant freshening and 

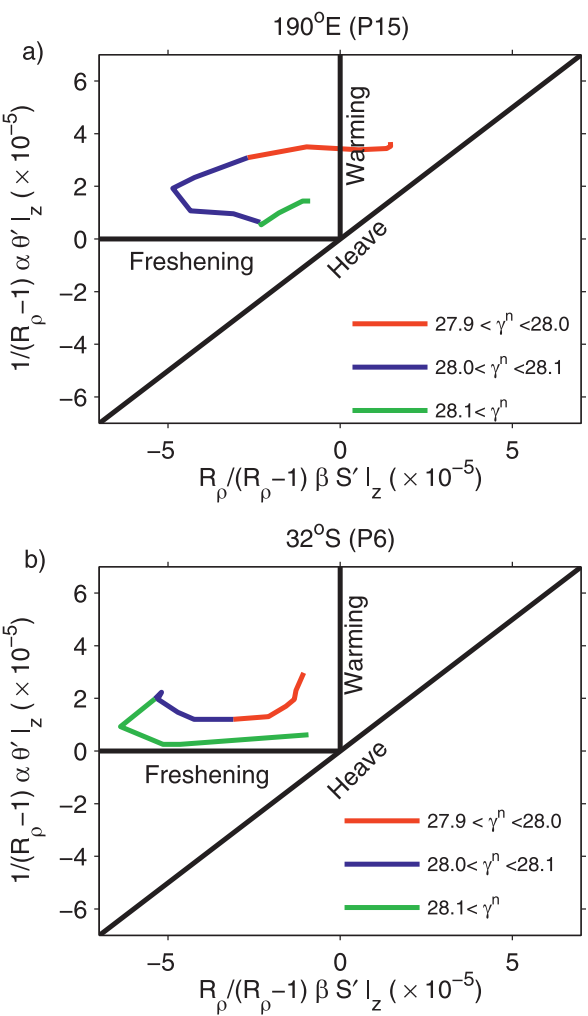

FIG. 7. Diagram of $R_{\rho} /\left.\left(R_{\rho}-1\right) \beta S^{\prime}\right|_{z}$ against $1 /\left.\left(R_{\rho}-1\right) \alpha \theta^{\prime}\right|_{z}$ as a function of $\gamma^{n}$ for (a) $170^{\circ} \mathrm{W}(\mathrm{P} 15)$ and (b) $32^{\circ} \mathrm{S}$ (P6). Pure freshening, warming, and heave through the origin are shown.

some warming of AABW have been documented in the Antarctic continental margins of the Ross Sea and along the Adélie Coast (Aoki et al. 2005; Rintoul 2007; Jacobs and Giulivi 2007). These studies have found decadal freshening for water in the Ross Sea's slope and coast currents and high-salinity shelf water from -0.08 to -0.03 decade $^{-1}$ (Jacobs and Giulivi 2007); Adélie Land bottom water for $\gamma^{n}>28.35 \mathrm{~kg} \mathrm{~m}^{-3}$ of -0.03 between 1994 and 2002 (Aoki et al. 2005); and farther west, at $115^{\circ} \mathrm{E}$, a freshening of continental shelf water south of $61^{\circ} \mathrm{S}$ of $-0.018 \mathrm{decade}^{-1}$ (Rintoul 2007). Freshening of bottom water downstream and offshore of the Antarctic continent has also been observed: in the northwest Ross Sea (depth $>1900 \mathrm{~m}$ ) as a freshening of -0.008 decade $^{-1}$ (Jacobs and Giulivi 2007) and in AABW in the AustralianAntarctic Basin in the deep western boundary current as a freshening of -0.008 decade $^{-1}$ (Rintoul 2007).

The deep salinity change in the southwest Pacific basin is two orders and one order of magnitude smaller than the salinity changes in the AABW formation regions along the Antarctic continent and bottom water in connecting Southern Ocean basins, respectively. The smaller freshening signal in the southwest Pacific basin may be explained by deep ocean mixing or time lag of advection of the freshening signal along the circulation pathway. While direct estimates of interior ocean mixing are not available, the suggestion that this may be an advection signal is supported by direct velocity observations at the deep western boundary of mean bottom velocity of $0.05 \mathrm{~m} \mathrm{~s}^{-1}$ (Whitworth et al. 1999). This equates to an advection of $14^{\circ} \mathrm{yr}^{-1}$ of latitude (Katsumata and Fukasawa 2011). However, Johnson and Orsi (1997), based on the northward advection of a deep ocean change above the salinity maximum, suggested a northward advection at the western boundary of $0.014 \mathrm{~m} \mathrm{~s}^{-1}$. The difference between the Lagrangian advection of the climate signal and the Eulerian current meter estimate may be due to eddies and recirculations (Johnson and Orsi 1997).

\section{Discussion and conclusions}

We find consistent decadal property changes-warming, freshening, increase in total inorganic carbon, and decrease in oxygen-near the deep western boundary of the southwest Pacific basin from $50^{\circ}$ to $20^{\circ} \mathrm{S}$. Near the western boundary, the deep ocean warming and freshening has resulted in a decrease in the bottom density and thinning of the Antarctic Bottom Water layer $\left(\gamma^{n}>\right.$ $28.1 \mathrm{~kg} \mathrm{~m}^{-3}$ ). While the primary focus of this paper is the AABW property change, we note that the overlying Circumpolar Deep Water, incorporating the remnant salinity maximum of North Atlantic Deep Water (Fig. $2 b$ ), shows decadal freshening, increased total inorganic carbon, and decrease in oxygen (Figs. 3b,c,d). These property changes are consistent with an increase in $\mathrm{Pa}$ cific Deep Water influence in this density layer and decrease in northward flow of $\mathrm{AABW}$ and CDW into the Pacific basin. Considering the relative roles of freshening, heating, or isopycnal heave as drivers of the deep ocean density decrease we find that the observed AABW stratification change is the result of both warming and freshening processes. The signal of deep ocean warming, freshening, and total carbon increase in the southwest Pacific basin directly links the observed midlatitude changes to Southern Ocean climate variability.

For the 1990s sections, CFC-11 and CFC-12 were found in the deep southwest Pacific basin (Talley 2007). Farther northward, advection of CFC-11 has been observed in the sections occupied during the 2000s. On the 2009 occupation of the $170^{\circ} \mathrm{W}(\mathrm{P} 15)$ section, there was measurable penetration of both CFC-11 and CFC-12 in the abyssal waters along the entire section and in the Samoan Passage (J. Bullister 2012, personal communication). Atmospheric CFC-11 and CFC-12 concentrations in the Southern Hemisphere rapidly increased during the 1970s, although some concentrations of these 
gases are found in the 1950s (Walker et al. 2000). CFCs enter the surface ocean by air-sea gas exchange and the ocean interior by water mass subduction. Given the CFC penetration into the southwest Pacific basin, we suggest that the warming, freshening, total carbon, and oxygen decadal changes we observe are the leading edge of an advection signal from the Southern Ocean and a signature of variability at the formation site of AABW in the Pacific and Indian sectors of the Southern Ocean prior to 1970. While high-latitude Southern Ocean observations prior to 1970s are limited, Jacobs et al. (2002) and Rintoul (2007) found freshening in the Ross Sea and Adélie Land, respectively, in the 1960s and that the rate of freshening has increased since the 1990s. While we have considered only the total carbon change, Murata et al. (2007) found a deep ocean anthropogenic carbon increase of $3.0 \mu \mathrm{mol} \mathrm{kg}^{-1} \mathrm{decade}^{-1}$ at $32^{\circ} \mathrm{S}$ between $180^{\circ}$ and $160^{\circ} \mathrm{W}$.

Analyses of time series sections in the deep southwest Pacific basin clearly show the spatial pattern of the property changes in the basin. The largest decadal property changes are found at the southern extreme of the deep basin where the property changes are strongly confined to the deep western boundary. These property changes, together with the penetration of CFC-11 and CFC-12 along the western boundary, suggest that the western boundary provides a mechanism to rapidly transmit high-latitude variability into the global deep ocean. While the southwest Pacific basin is remote from AABW formation in the Ross Sea and Adélie Land, this study and previous results (e.g., Johnson and Orsi 1997; Masuda et al. 2010; Katsumata and Fukasawa 2011) dispel the notion that the deep ocean is quiescent. Highlatitude climate variability is being directly transmitted into the deep southwest Pacific basin and the global deep ocean through dynamic deep western boundary currents.

Acknowledgments. The observational data were collected by Australian, Japanese, and United States nationally funded programs that contribute to GO-SHIP (www.go-ship.org). We thank all scientific and ship personnel who enabled the collection of these data. BMS, SEW, and BT were supported by the Australian Climate Change Science Program, funded jointly by the Department of Climate Change and Energy Efficiency and CSIRO. Funding for AM was provided through NOAA Grant NA110AR4310063. The comments of two reviewers greatly improved the manuscript.

\section{REFERENCES}

Anderson, L. A., and J. L. Sarmiento, 1994: Redfield ratios of remineralization determined by nutrient data analysis. Global Biogeochem. Cycles, 8, 65-82.
Aoki, S., S. R. Rintoul, S. Ushio, S. Watanabe, and N. L. Bindoff, 2005: Freshening of the Adélie Land bottom water near $140^{\circ} \mathrm{E}$. Geophys. Res. Lett., 32, L23601, doi:10.1029/2005GL024246.

Bindoff, N. L., and T. J. McDougall, 2000: Decadal changes along an Indian Ocean section at $32^{\circ} \mathrm{S}$ and their interpretation. J. Phys. Oceanogr., 30, 1207-1222.

Carmack, E. C., 1990: Large scale physical oceanography of polar oceans. Polar Oceanography Part A: Physical Science, W. O. Smith Jr., Ed., Academic Press, 171-222.

Hood, E. M., C. L. Sabine, and B. M. Sloyan, cited 2010: The GO-SHIP repeat hydrography manual: A collection of expert reports and guidelines. IOCCP Rep. 14, ICPO Publication Series Number 134. [Available online at http://www.go-ship. org/HydroMan.html.]

Intergovernmental Oceanographic Commission, 2010: The international thermodynamic equation of seawater 2010: Calculation and use of thermodynamic properties. UNESCO Tech. Rep. 56, 196 pp.

Jackett, D. R., and T. J. McDougall, 1997: A neutral density variable for the world's oceans. J. Phys. Oceanogr., 27, 237-263.

Jacobs, S. S., and C. F. Giulivi, 2007: Large multidecadal salinity trends near the Pacific-Antarctic continental margin. J. Climate, 23, 4508-4524.

,-- , and P. A. Mele, 2002: Freshening of the Ross Sea during the late 20th century. Science, 297, 386-389, doi:10.1126/ science.1069574.

Johnson, G. C., and A. H. Orsi, 1997: Southwest Pacific Ocean water mass changes between 1968/69 and 1990/91. J. Climate, 10, 306-316.

— tom water warming. Geophys. Res. Lett., 33, L14614, doi:10.1029/2006GL026769.

— S. Mecking, B. M. Sloyan, and S. E. Wijffels, 2007: Recent bottom water warming in the Pacific Ocean. J. Climate, 20, 5365-5375.

— S. G. Purkey, and J. L. Bullister, 2008: Warming and freshening in the abyssal southeastern Indian Ocean. J. Climate, 21, 5351-5363.

Katsumata, K., and M. Fukasawa, 2011: Changes in meridional fluxes and water properties in the Southern Hemisphere subtropical oceans between 1992/1995 and 2003/2004. Prog. Oceanogr., 89, 61-91.

Kawano, T., M. Aoyama, T. Joyce, H. Uchida, Y. Takatsuk, and M. Fukasawa, 2006a: The latest batch-to-batch difference table of standard seawater and its application to the WOCE onetime sections. J. Phys. Oceanogr., 62, 777-792.

— M. Fukasawa, S. Kouketsu, H. Uchida, T. Doi, I. Kaneko, M. Aoyama, and W. Schneider, 2006b: Bottom water warming along the pathway of lower circumpolar deep water in the Pacific Ocean. Geophys. Res. Lett., 33, L23613, doi:10.1029/ 2006 GL027933.

Kouketsu, S., and Coauthors, 2011: Deep ocean heat content changes estimated from observations and reanalysis product and their influence on sea level change. J. Geophys. Res., 116, C03012, doi:10.1029/2010JC006464.

Masuda, A., and Coauthors, 2010: Simulated rapid warming of abyssal North Pacific waters. Science, 329, 319-322, doi:10.1126/ science. 1188703 .

McCartney, M. S., and K. A. Donohue, 2007: A deep cyclonic gyre in the Australian-Antarctic basin. Prog. Oceanogr., 75, 675-750.

McDougall, T. J., and P. M. Barker, 2011: Getting started with TEOS-10 and the Gibbs Seawater (GWS) Oceanographic Toolbox. SCOR/IAPSO Tech. Rep. WG127, 28 pp. 
Murata, A., Y. Kumamoto, Y. S. Watanabe, and M. Fukasawa, 2007: Decadal increases of anthropogenic $\mathrm{CO}_{2}$ in the South Pacific subtropical ocean along $32^{\circ}$ S. J. Geophys. Res., 112, C05033, doi:10.1029/2005JC003405.

Purkey, S. G., and G. C. Johnson, 2010: Warming of the global abyssal and deep Southern Ocean between the 1990s and the 2000s: Contributions to global heat and sea level rise budgets. J. Climate, 23, 6336-6351.

- , and —, 2012: Global contraction of Antarctic Bottom Water between the 1980s and 2000s. J. Climate, 25, 5830-5844. , and - 2013: Antarctic Bottom Water warming and freshening: Contributions to sea level rise, ocean freshwater budgets, and global heat gain. J. Climate, 26, 6105-6122.

Rintoul, S. R., 1998: On the origin and influence of Adélie Land bottom water. Ocean, Ice and Atmosphere: Interactions at the Antarctic Continental Margin, S. Jacobs and R. Wiess, Eds. Antarctic Research Series, Vol. 75, American Geophysical Union, 151-171.

, 2007: Rapid freshening of Antarctic Bottom Water formed in the Indian and Pacific Oceans. Geophys. Res. Lett., 34, L06606, doi:10.1029/2006GL028550.

Roemmich, D., S. Hautala, and D. Rudnick, 1996: Northward abyssal transport through the Samoan Passage and adjacent regions. J. Geophys. Res., 101 (C6), 14 039-14055.
Smith, W. H. F., and D. T. Sandwell, 1997: Global seafloor topography from satellite altimetry and ship depth soundings. Science, 277, 1957-1962.

Talley, L. D., 2007: Pacific Ocean. Vol. 2, Hydrographic Atlas of the World Ocean Circulation Experiment (WOCE), M. Sparrow, P. Chapman, and J. Gould, Eds., International WOCE Project Office, $326 \mathrm{pp}$.

Uchida, H., H. Yamamoto, K. Ichikawa, I. Kaneko, M. Fukasawa, T. Kawano, and Y. Kumamoto, 2007: Flow of abyssal water into Wake Island Passage: Properties and transports from hydrographic surveys. J. Geophys. Res., 112, C04008, doi:10.1029/ 2006JC004000.

Walker, S. J., R. F. Weiss, and P. K. Salameh, 2000: Reconstructed histories of the annual mean atmospheric mole fractions for the halocarbons CFC-11, CFC-12, CFC-113, and carbon tetrachloride. J. Geophys. Res., 105 (C6), 14285-14296.

Whitworth, T., III, B. A. Warren, W. D. Nowlin Jr., S. B. Rutz, R. D. Pillsbury, and M. I. Moore, 1999: On the deep westernboundary current in the southwest Pacific basin. Prog. Oceanogr., 43, $1-54$.

Zenk, W., and E. Morozov, 2007: Decadal warming of the coldest Antarctic Bottom Water flow through the Vema Channel. Geophys. Res. Lett., 34, L14607, doi:10.1029/ 2007GL030340. 